\title{
Ebeveynlerin Mahallelerine Yönelik Sağlık Güvenliği Algısı: COVID-19 Salgını Öncesi ve Sonrası İçin Karşıyaka'da Bir Araştırma*
}

\author{
Gözde Ekşioğlu \\ Çetintahra ${ }^{1}$ \\ ORCID: 0000-0001-9746-495X
}

\author{
Senem Tezcan ${ }^{2}$
}

ORCID: 0000-0003-0532-8825
Bedriye Çınar ${ }^{3}$

ORCID: 0000-0003-2009-0763

Öz

COVID-19 pandemisiyle mücadele kapsamında alınan önlemler, çocukların dış mekan etkileşimini kısıtlamakta ve halihazırda önemli bir halk sağhlğı sorunu olan çocuklarda fiziksel aktivite eksikliğini olumsuz açıdan arttıran bir etki yaratmaktadır. Güncel durumda dı̧̧ mekan kısıtlamalarının fiziksel aktivite eksikliğine neden olduğu tartışlmaktayken, ileriki dönemde yaşanılan mahalleye ya da kentsel alanlara ilişkin oluşacak sağllk güvenliği algistnın, çocukların fiziksel aktivitelerini gerçekleştirecekleri dış mekan tercihlerinde de etkili olabileceği göz önünde bulundurulmalıdır. Bu çalışmada pandemi dönemi öncesi ve sonrasında çocukların fiziksel aktivite yaptı̆̆ı mekanlardaki değişimleri belirlemek ve bu değişimler üzerinden pandemi temelli bir sağlık güvenliği algısının oluşup oluşmadı̆̆ıı tespit etmek amaçlanmıştır. Çalışma kapsamında pandemi döneminde Karşıyaka ilçesinde 27 devlet ilkokulunda eğitim almış çocuğu olan 1559 ebeveyn ile çevrimiçi bir anket yapılmuştır. Sonuçlar, pandemi öncesine göre fiziksel aktivite mekanında değişimler olduğuna, bu değişimin fiziksel aktivite yapılan mekanların temizlik ölçütü üzerinden gelişen bir "sağlık güvenliği algısı" nedeniyle oluştuğuna ilişkin ipuçları barındırmaktadır. Bu çalışma, COVID-19 ile kentsel mekan kullanımı arasındaki ilişkiye dair kentsel tasarım literatürüne önemli bir katkı koyacaktır.

Anahtar Kelimeler: COVID-19, sağlık güvenlï̆i algısı, mahalle, çocuk, fiziksel aktivite

\footnotetext{
* Bu makale çalışması "5.Kent Araştırmaları Kongresi"nde bidiri olarak sunulmuştur.

${ }^{1}$ Dr. Öğr. Üyesi., Dokuz Eylül Üniversitesi, E-mail: gozde.eksioglu@deu.edu.tr

${ }^{2}$ Dr.,E-mail: senemtzcn@gmail.com

${ }^{3}$ E-mail: bedriyecinar21@gmail.com

idealkent @ C Kent Araştırmaları Dergisi (Journal of Urban Studies)

http://idealkentdergisi.com

Geliş Tarihi Received Date: 27.11.2020 Kabul Tarihi Accepted Date: 20.04.2021
} 


\title{
Parents' Perception of Neighborhood's Health Safety: An Investigation in Karsiyaka for Pre and Post COVID-19 Outbreak ${ }^{4}$
}

\author{
Gözde Ekşioğlu \\ Çetintahra ${ }^{5}$ \\ ORCID: 0000-0001-9746-495X
}

Senem Tezcan ${ }^{6}$

ORCID: 0000-0003-0532-8825
Bedriye Çınar ${ }^{7}$

ORCID: 0000-0003-2009-0763

\begin{abstract}
The arrangements taken to combat the COVID-19 pandemic not only cause limitations on children's open space interaction but also increase the lack of physical activity in children, which is already a major public health problem. While it is argued that open space restrictions cause a lack of physical activity in the current situation, it should be taken into account that the health safety perception on the neighborhood or urban areas in the future may also be effective in the physical activity place preferences of children. This study aimed to determine the changes in the places where children do physical activity before and after the pandemic period and to determine whether a pandemic-based health safety perception on the neighborhood is formed through these changes. In this study, an online survey was conducted with 1559 parents with children who were educated in 27 public primary schools in Karşryaka province during the pandemic period. Results clued in the changes in physical activity place compared to before pandemic, and these changes develop a health safety perception over the cleanliness criteria of the physical activity places. This study will contribute important data to urban design literature on the relation between COVID-19 and urban space use.
\end{abstract}

Keywords: COVID-19, health safety perception, neighborhood, child, physical activity

\footnotetext{
${ }^{4}$ This study was prepared with the data obtained from the TUBITAK Project (1001) numbered 120K672 and titled "Health Safety Perception for Urban Space of Children and Their Parents who Cannot Leave Their Homes in the Process of Combating the Covid-19 Outbreak and Possible Effects of Children's Physical Activity Levels in the Normalization Process". The methodology of the study was approved by the DEU Science and Engineering Sciences Research and Publication Ethics Board.

${ }^{5}$ Assist. Prof. Dr., Dokuz Eylül University, E-mail: gozde.eksioglu@deu.edu.tr

${ }^{6}$ PhD.,E-mail: senemtzcn@gmail.com

${ }^{7}$ E-mail: senemtzcn@gmail.com

id ealkent (c) Kent Araştırmaları Dergisi (Journal of Urban Studies)

http://idealkentdergisi.com

Geliş Tarihi Received Date: 27.11.2020 Kabul Tarihi Accepted Date: 20.04.2021
} 


\section{Giriş}

11 Mart 2020 tarihinde Dünya Sağlık Örgütü (DSÖ) tarafından pandemi olarak ilan edilen yeni koronavirüs salgını ile mücadele kapsamında kentsel yaşantının alışılagelen düzenini değiştirecek bir dizi önlem alınması gerekmiştir. Virüsün damlacık yolu ile bulaşması (Heymann ve Shindo, 2020) sonucunda maske kullanımı, fiziksel mesafe ve birçok ülkede uygulanan sokağa çıkma yasakları gibi kuralların getirilmesine neden olmuştur.

Ülkemizde 16 Mart 2020 tarihi itibariyle okullar ve üniversiteler kapatilmış, 3 Nisan - 1 Haziran 2020 tarihleri arasında 20 yaş ve altı bireyler için sokağa çıkma yasağı getirilerek kentsel mekanla ilişkileri kısıtlanmıştır. Kuşkusuz bu uygulamalar, pandemi ile mücadelede gereklidir. Ancak uzun süre kapalı alanda kalan gelişim çağındaki çocukların, ileriki dönemlerde sosyolojik (Christoffel vd., 2020; Yoshikawa, vd, 2020), psikolojik (Armitage ve Nellums, 2020; Korczak ve Madigan ve Colasanto, 2017; Viner vd., 2020; Wang, Zhang, Zhao, Zhang ve Jiang, 2020) ve fiziksel (An, 2020; Guerrero, vd, 2020; Hemphill vd., 2020; Shekerdmian, vd, 2020) sorunlarla karşılaşabilecekleri tartışılmaktadır. Sürecin birey ve toplum sağlığı üzerindeki etkilerinin ve bu etkilere yönelik koruyucu/tedavi edici yöntemlerin belirlenmesinde sağlık uzmanlarının katkısı oldukça önemlidir. Aynı zamanda kişinin fiziksel, sosyal ve psikolojik iyilik halini (bir başka deyişle sağlığını) kentsel mekanda sürdürmesine olanak sağlayan araçlar barındıran mekansal planlamanın (Çetintahra ve Hepgüzel, 2014), salgın sürecinin (ve esasen sonrasının) kentsel yaşam kalitesine ve mekânsal tercihlere olası etkisine yönelik bilimsel bilgi üretmesi ve müdahale araçları geliştirmesi gerekli olacakttr.

'Fiziksel, sosyal ve ruhsal iyilik hali' olarak tanımlanan sağlık için gerekli olan bireysel davranış biçimlerinden birisi de fiziksel olarak aktif olmaktır (World Health Organization [WHO], 2010). Öyle ki fiziksel aktivitenin eksikliği (ya da hareketsizliğin artışı) vücut kompozisyonu, kalp sağlığı, kas iskelet sistemi, bağışıklık sistemi ve psiko-sosyal durum ile ilgili olumsuzluklara neden olabilmektedir (Zorba, 2006). COVID-19 öncesindeki bilimsel yazında DSÖ, gelecek nesillere olası etkisinden dolayı çocukluk döneminde yaşanan fazla kiloluluk ve obezitenin küresel ölçekte en önemli halk sağlığı sorunlarından birisi olduğunu ileri sürmekte ve obeziteyle mücadelede fiziksel aktivitenin önemini vurgulamaktadır (WHO, 2014). Halihazırda TV, bilgisayar ve internetin yaygın olarak kullanımı, ailelerin çocuklarının akademik başarısına yönelik beklentileri, kentsel mekanın kısıtlı olanakları ya da çocuk ve/veya ebeveynin kentsel mekana ilişkin kaygıları nedeniyle çocukların dış mekanda 
yeterli zaman geçirememesi gibi faktörler, fiziksel aktivite düzeyini azaltmakta (Kail, 2002; Thorleifsdottir, 2008) ve çocukların daha sedanter (hareketsiz) bir yaşam tarzı sürdürmelerine neden olmaktadır.

Sürekli kapalı alanda bulunan çocukların, iç mekanda (evlerinde) yapacakları fiziksel aktivite şiddetinin sedanter ve düşük şiddette olacağı öngörülmektedir (Prince, Butler, Rao ve Thompson, 2017). Ancak fazla kiloluluk ve obezite ile mücadelede orta ve yüksek şiddette fiziksel aktivitenin gerçekleştirilmesi önemlidir. Yapılan çalışmalarda, çocukların iç mekandan çok dış mekanda (Çetintahra ve Çubukçu, 2019; Prince vd., 2017), özellikle de yaşadıkları mahallede, konutlarının yakın çevresindeki alanlarda (Çetintahra, 2015) gerçekleştirdikleri fiziksel aktivitelerin, orta ve yüksek şiddette fiziksel aktiviteyi karşılamada en önemli mekanlar olduğu ileri sürülmektedir. Dolayısıyla çocukların sağlık düzeylerini arttırmak için fiziksel olarak aktif olmaları; fiziksel aktivite gerekliliklerini karşılayabilmek için ise kentsel alanlarda orta ve yüksek şiddette fiziksel aktivite yapmaları gereklidir. Ancak COVID-19 salg1$\mathrm{n}$ ile birlikte getirilen kısıtlamalar, bu gereklilikleri karşılamayı zorlaştırmaktadir.

Salgının ne zaman biteceği bilinmiyor olsa da kontrol altına alındığı andan itibaren hayatın normal düzenine dönmesiyle birlikte çocukların fizyolojik, psikolojik ve sosyolojik gereksinimlerini gerçekleştirebilmeleri için kentsel mekanla yeniden etkileşimde bulunması gerekecektir. Ancak burada önemli bir nokta, kentsel mekanla tekrar etkileşime girme istekliliği olacaktır. Dolayısıyla, "eski normale" dönebilmek için COVID-19 salgını bittiğinde insanların mekâna ilişkin sağlık güvenliği algısının ne olacağı bilinmeli, bu algının kentsel mekanda vakit geçirme tercihini etkileyip etkilemeyeceği araştırılmalıdır. Bu çalışmada (1) ilkokul eğitim düzeyindeki (6-11 yaş grubu) çocukların fiziksel aktivitelerini gerçekleştirdikleri dış mekanların tercihinde, COVID-19 öncesi ve sonrası döneme göre değişimleri tespit etmek ve (2) değişim durumunda bunun ebeveynin mahallesine yönelik bir sağlık güvenliği algısı nedeniyle oluşup oluşmadığını belirlemek hedeflenmiştir. Çalışma kapsamında İzmir ili Karşıyaka ilçesinde yer alan 27 devlet ilkokulunda pandeminin ortaya çktığı dönemde (2019-2020 Eğitim Yılı) eğitim almış 1., 2., 3. ve 4. sınıf öğrencilerinin ebeveynlerine, çevrimiçi bir anket formu ulaştırılmıştır. Anketi tamamlayan 1559 ebeveynin cevapları, betimsel ve çıarımsal istatistiksel yöntemlerle analiz edilerek bulgular tartışılmıştır. 


\section{Çocukların Fiziksel Aktivite Düzeyini ve Konumunu Etkileyen Faktörler}

COVID-19 öncesi bilimsel yazında çocukların fiziksel aktivite düzeylerinde demografik, biyolojik, psikolojik, algısal, duygusal, davranışsal, gelişimsel, sosyal çevre ve fiziksel çevre gibi birçok değişkenin etkili olduğunu ileri sürmektedir (ayrıntılı literatür taraması için bkz. Brodersen, Steptoe, Williamson ve Wardle, 2005). Bu çalışmada söz konusu değişkenlerden (1) ebeveynin demografik göstergelerine, (2) çocuğun gelişimsel özelliklerine ve (3) fiziksel çevrenin algisal niteliklerine odaklanılmıştır.

\section{Fiziksel Aktivite Düzeyini Etkileyen Demografik Özellikler}

Çocuğun fiziksel aktivite düzeyinde etkili olduğu ileri sürülen ailenin sosyo-ekonomik durumunu yansitan demografik göstergeler, hanehalkı gelir düzeyi, ebeveynin eğitim durumu ve iş durumu, sosyo-ekonomik statü gibi değişkenler üzerinden tartışılmaktadır. Yapılan çalışmalar, hanehalkı gelir düzeyinin çocuğun fiziksel aktivite düzeyini ve mekanın etkileyen bir değişken olduğunu ileri sürülmektedir (Kemperman ve Timmermans, 2011; Nader, Bradley, Houts, McRitchie ve O'Brien, 2008; Shi, Lien, Kumar ve Holmboe-Ottensen, 2006). Buna göre, düşük gelir durumunun kız çocuklarda, yüksek gelir durumunun erkek çocuklarda fiziksel aktiviteyi (Shi, vd, 2006) ve sportif faaliyetlere katılımı (Kemperman ve Timmermans, 2011) arttırdığ1 bulgularla desteklenmektedir. Dolayısıyla sosyo-ekonomik statü ile çocukların fiziksel aktivite düzeyleri arasında bir ilişki olduğu, ancak ilişkinin yönünün, çocuğun cinsiyeti, yaşı, hanehalkı gelir düzeyinin düşük ya da yüksek olmasına göre farklılık gösterebileceği belirtilmektedir.

Demografik değişkenlerden ailenin eğitim düzeyinin çocuğun fiziksel aktivitesinde etkili olduğu, tartısılan bir husustur. Bir kısım çalışmada ebeveynin eğitim düzeyinin artmasıyla, çocuğun dış mekanda yaptığı fiziksel aktivitenin azaldığı ileri sürülürken, bir kısım çalışmada ise tersine bir durum vurgulanmaktadır (Aarts vd., 2010; Singh vd, 2008). Dolayısıyla, ebeveynin (ya da ailenin) eğitim düzeyi ile çocuğun fiziksel aktivitesi arasında bir ilişki olduğu, ancak ilişkinin yönünün değişkenlik gösterdiği söylenebilir. Bu çalışma kapsamında da ebeveynin eğitim ve iş durumu ve hane halkının gelir düzeyi bilgileri elde edilmiştir. Bu bilgiler yardımıyla Türkiye İstatistik Kurumu (TÜIKK)'nun sosyo-ekonomik statü (SES) tablosu üzerinden ebeveynin SES grubu belirlenmiştir. 


\section{Fiziksel Aktivite Düzeyini Etkileyen Gelişimsel Özellikler}

Çocukların fiziksel aktivite düzeyleri ve konumlarını etkileyen değişkenlerin incelendiği çalışmalarda çocuğun cinsiyetinin (Hesketh vd., 2008; Hume vd., 2009; Li, Dibley, Sibbritt ve Yan, 2006; Nader vd, 2008; Sallis vd., 1999) ve yaşının (Brodersen vd., 2005; Guillaume, Lapidus, Bjömtop ve Lambert, 1997; Sunnegårdh, Bratteby ve Sjölin, 1985) etkili değişkenler olduğu vurgulanmaktadır. Yapılan bilimsel çalışmalar, erkek çocukların kız çocuklara göre daha aktif olduklarını, yaş açısından ise 10 yaşın bir eşik değer olduğunu ve yaşın artması ile aktivite düzeylerinde de değişimler gözlendiğini ileri sürmektedir (ayrıntlı literatür taraması için bkz. Çetintahra, 2015).

Boy ve kilo, çocuğun gelişimsel özellikleri kapsamında değerlendirilmektedir. Ancak boy ve kilo değişkenleri, fiziksel aktivite ile tekil olarak ilişkilendirilmekten çok, Beden Kitle İndeksi (BKI) değeri üzerinden incelenmektedir. Yapılan çalışmalar, BKİ arttıkça hem erkek hem de kız çocuklarda fiziksel aktivite düzeyinde azalma olduğunu ileri sürmektedir (Adkins vd., 2004; Brodersen vd., 2005; Nader, vd, 2008). Bu çalışma kapsamında da BKİ değerinin hesaplanabilmesi için ebeveynlerden, çocuklarının güncel boy ve kilo bilgileri elde edilmiştir.

\section{Fiziksel Aktivite Düzeyini Etkileyen Fiziksel Çevrenin Algısal Özellikleri}

Çocuğun fiziksel aktivite düzeyinde fiziksel çevrenin ya da kentsel mekanların niteliklerinin önemli olduğu literatürde sıklıkla vurgulanmaktadır (Burdette ve Whitaker, 2005; Frank, Andresen ve Schmid, 2004; Hill, Wyatt, Reed ve Peters, 2003; Lopez, 2004; Saelens vd., 2002; Saelens, Sallis, Black ve Chen, 2003). Çocukların aktivitelerini gerçekleştirdikleri mekanların, fiziksel çevre niteliklerinin yanı sıra, çevrenin algısal özelliklerinin de çocuğun aktivitesi üzerinde etkili olduğu bulgularla desteklenmektedir (Hunter vd., 2020). Buna göre çocuğun fiziksel aktivite düzeyinin, çevrenin fiziksel niteliklerinin sunduğu olanakların çocuk tarafından algılaması ile ilişkili olacağı ileri sürülmektedir (Evans, 2003; Heft, 1988). Bir başka ifadeyle, fiziksel çevrenin nitelikleri, çocuğun (kimi durumlarda ebeveynin) bunu nasıl algiladığı ve bu algı doğrultusunda söz konusu alanda neleri yapabileceğinin kararını vermesi ile ilişkilidir.

Yalnızca çocuğun değil, ebeveynin de mekana yönelik algısal değerlendirmelerinin, çocuğu nerede aktiviteye yönlendireceğinin tercihinde etkili olacağı açıktır. Dolayısıyla ebeveyn, çocuğun fiziksel aktivitesinin türü, düzeyi ve aktivitenin gerçekleştirileceği mekanın tercihinde önemli bir etkendir (Adkins vd., 2004; Dozier, Schroeder, Lee, Fulkerson ve Kubik, 2020; Hume 
vd., 2009; Nezami, Zarei, Tojari ve Hazeveh, 2020; Sallis vd., 1999). Bu sav, Bronfenbrenner'in (1977) geliştirdiği 'ekolojik model' üzerinden de desteklenmektedir. Buna göre, çocuğun gelişiminde birincil düzeydeki etken, mikrosistem olarak tanımlanan ailesidir (Bronfenbrenner, 1977). Mikrosistemin mekansal izdüşümü olarak konut ve konut yakın çevresi kabul edildiğinde, bu mekanların niteliklerinin de çocuğun davranışında etkili olacağı göz önünde bulundurulmalıdır.

Çocuğun yaşadığı konut yakın çevresinin (ya da mahallesinin) algısal nitelikleri, ilgili literatürde trafik güvenliği algısı (Handsa vd., 2018; Hume vd., 2009; Timperio, Crawford, Telford ve Salmon, 2004; Trapp vd., 2012), suç güvenliği algısı (Galaviz, Zytnick, Kegler ve Cunningham, 2016; Kemperman ve Timmermans, 2011; Molnar, Gortmaker, Bull ve Buka, 2004; Zhang, Zhang, Gan, Li ve Rhodes, 2019), mahallenin algılanan estetik ve ilgi çekicilik düzeyleri (Hume, Ball ve Salmon, 2006; Hume, Salmon ve Ball, 2007; Mota, Almeida, Santos ve Riberio, 2005; Zhang vd., 2019) üzerinden tartısılmaktadır.

Kuşkusuz bu değişkenlerin, COVID-19 sonrasında da etkili olabileceği göz önünde bulundurulmalıdır. Ancak mekanın algısal değişkenlerinden birisinin "kişinin bulunduğu mekana ilişkin sağlık güvenliği algısı" olacağı öngörülmelidir. Algısal süreçlerin davranışa etkisi düşünüldüğünde, COVID-19 salgını gibi bir süreci yaşayan bireylerde "mekanın sağlık güvenliği algısının" mekânsal davranışa ne düzeyde etki edeceği, şehir planlama ve kentsel tasarım literatüründe tartışılması gereken bir husustur.

Özetle, çocuğun cinsiyeti, yaşı, BKİ değeri gibi gelişimsel; ailenin eğitim durumu, gelir düzeyi, SES göstergeleri gibi sosyo-demografik ve fiziksel çevrenin trafik ve güvenlik algısı, estetik ve ilgi çekicilik düzeyleri gibi algısal niteliklerinin, çocuğun fiziksel aktivite düzeyinde etkili olduğu önceki çalışmalarda vurgulanmaktadır. Aynı zamanda çocuğun gerçekleştirdiği fiziksel aktivitenin, diş mekanlarda daha yüksek seviyede olduğu da ileri sürülmektedir. Bu çalışmada ileri sürülen bu savların COVID-19 sonrasında ne şekilde değiştiği, fiziksel çevrede pandemi ile birlikte bir sağlık güvenliği algısı niteliğinin oluşup oluşmadığı ve bulguların, pandemi öncesi bilimsel yazından ne düzeyde farklılaştığı tartısılacaktır.

\section{Yöntem}

Bu çalışma, "COVID-19 sonrası çocukların ve ebeveynlerin kentsel mekana ilişkin 'sağlık güvenliği algısını' belirleyerek, yaşadıkları mahallelerde bulunan dış mekan fiziksel aktivite imkanlarına ilişkin görüşlerini elde etmek ve böylece çocuk / ebeveyn çiftlerinin yaşadıkları mahallelerde COVID-19 sonra- 
sı hangi mekanları kullanılabilir ya da kullanılamaz olarak algıladıklarını tespit etmeyi amaçlayan" bir TÜBITTAK projesinden elde edilen veriler üzerinden geliştirilmiştir. Çalışmanın verisi, çevrimiçi bir anket uygulama aracı ile elde edilmiş ve çalışma 1559 ebeveynin katıldığ "COVID-19 Sürecinde Çocukların Fiziksel Aktivite Düzeyi ve Sağlık Güvenliği Algısı Anketi" sonuçlarından oluşturulmuştur. Çalışmanın yöntemi DEÜ Fen ve Mühendislik Bilimleri Araştırma ve Yayın Etiği Kurulu'ndan onay alınmış, çalışmada anket uygulamasının yapılabilmesi için İzmir İl Milli Eğitim Müdürlüğü, Karşıyaka İlçe Milli Eğitim Müdürlüğü ile Karşıyaka ilçesinde bulunan 27 devlet ilkokulundan izin yazıları temin edilmiştir. Bu bölümde çalışma alanı, örneklem seçimi, anketin uygulanma süreci, anketin içeriği ve katılımcların özellikleri aktarılacaktır.

\section{Çalışma Alanı, Örneklem Seçimi ve Anket Uygulama Süreci}

Çalışmanun analizlerinin yapılabilmesi için İzmir ili içerisinde yer alan ve halihazırda Türkiye Sağlıklı Kentler Birliği ve DSÖ Sağlıklı Kentler Avrupa Ağı üyesi olan Karşıyaka ilçesi seçilmiştir. Karşıyaka ilçesi genelinde kentleşme ve kentsel nüfus yoğunluğu fazla olmakla birlikte, mekânsal yapı açısından da farklı yapılaşma biçimleri (kapalı siteler, kooperatif yapılaşmaları, dönüşüm alanları, farklılaşan bina-parsel dokusu, gibi) yer almaktadır (Şekil 1). İlçede 27 mahalle bulunmaktadır. İlçenin kuzeyinde yer alan Yamanlar ve Sancaklı, seyrek nüfus yoğunluğu olan mahallelerdir. İçe içerisinde, 17 farklı mahalleye dağılmış 27 adet devlet ilkokulu bulunmaktadır. Bu okullar dışında çalışma alanında birçok özel ilkokul bulunmaktadır ancak çalışma kapsamında yalnızca devlet ilkokullarına odaklanılmıştır. İlçenin sosyodemografik yapısı farklılıklar gösterse de devlet okulunda birçok farklı sosyal yapıdan ailenin çocuğu eğitim aldığından, örneklem çeşitliliği sağlanabilmiştir.

Anket formunu oluşturmak için çevrimiçi bir anket portalının uygulaması kullanılmıştır. Söz konusu uygulama ile anket formuna giriş yapılabilmesi için otomatik bir bağlantı adresi oluşturulmakta, anket formu mobil cihazlar ve/veya bilgisayardan bağlantı adresi üzerinden doldurulabilmektedir. Anketi dolduracak katılımcının tek bir cihazdan bir giriş yapabileceği ve istendiğinde anketten çıkarak, daha sonra ankete kaldığı yerden devam edebileceği şekilde anket formu düzenlenmiştir.

Katılımcıların belirlenmesi için amaçlı durum örnekleme yöntemi kullanılmıştır. 2020 Ağustos ayı içerisinde ilkokulların yönetimleri ile görüşülmüş ve anket bağlantı adresi okul müdür ve müdür yardımcıları vasıtasıyla sınıf 
öğretmenlerine iletilmiştir. Sınıf öğretmenleri, sınıflarının iletişim kanallarına bağlantı adresini göndermiş ve velileri anketi doldurmaları konusunda teşvik etmiştir. Anket yanıtları, anket bağlantı adresinin dağıtılmaya başlanmasından itibaren kaydedilmiş ve anket giriş sayıları ile anket tamamlanma oranları günlük olarak takip edilmiştir. Anket girişlerinde ve tamamlanma sayılarında durağanlaşmanın yaşandığı dönemler düzenli olarak kontrol edilmiş ve gerek okul yöneticileri ve öğretmenler ile tekrar görüşmeler yapılarak, gerekse anketi yarım bırakan ve iletişim numarasına ulaşılabilen katılımcılar aranarak anketi tamamlamaları için iletişime geçilmiştir. Süreç, Ağustos ayının ilk haftasında başlamış, veri girişinde azalmanın ve vaka sayılarında artışın yaşandığı Eylül ayının son haftasında tamamlanmıştır.

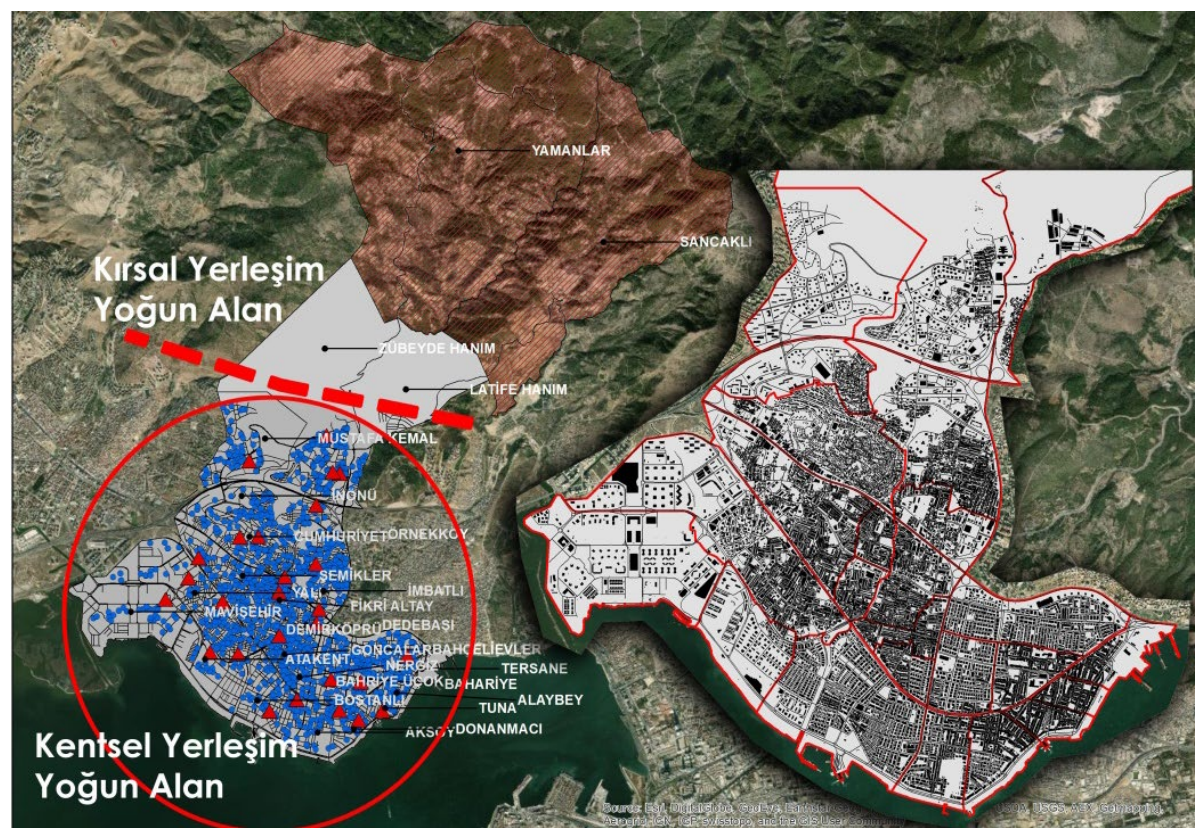

Şekil 1. Karşıyaka ilçesi ve çalışmanın örnekleminin mahallelere göre dağılımı (Soldaki şekilde, mavi noktalar katılımcıları, kırmızı üçgenler anket yapılan okulları göstermektedir; kırmızı ile taranan Yamanlar ve Sancaklı mahallerinden katılım olmamıştır. Sağdaki şekil, kentsel yerleşim alanlarının yoğun olarak yer aldığı mahallelerin yapı bazında formunu göstermektedir.

\section{“COVID-19 Sürecinde Çocukların Fiziksel Aktivite Düzeyi ve Sağlık Güvenliği Algısı Anketi" İçeriği}

Çocukların fiziksel aktivite düzeylerine odaklanan geniş örneklemin hedeflendiği çalışmalarda anket yönteminin, düşük maliyetli olması ve kısa bir 
sürede veri toplanabilmesi nedeniyle daha sık tercih edilen bir yöntem olduğu ileri sürülmektedir (Aarts vd., 2010; Hesketh vd., 2008; Kemperman ve Timmermans, 2011; Singh vd., 2008). Anket yönteminin öznel değerlendirmeler içermesi ve olanı değil arzu edileni verebilme olasılığı (Telford, Salmon, Jolley ve Crawford, 2004) göz önünde bulundurulmalıdır. Ancak yaşadığımız salgın döneminde kişilerin değerlendirmelerini içeren veriye en hızlı biçimde ulaşabilmek için internet üzerinden uygulanan çevrimiçi anketlerin önemli bir araç olduğu belirtilmektedir (Geldsetzer, 2020). Bu nedenle bu çalışma kapsamında da çevrimiçi olarak doldurulabilecek bir anket hazırlanmıştır. Anket formunda katılımcı özellikleri, çocuğun gelişimsel özellikleri, ailenin demografik durumu, COVID-19 öncesi ve sonrasında çocuğun gerçekleştirdiği fiziksel aktivitenin konumu, COVID-19 öncesi ve süreç boyunca ebeveynin çocukları için yaşadıkları mahalleye ilişkin algısal değerlendirmelerini içeren geniş kapsamlı sorular yer almıştır.

\section{Katılımcı Özellikleri, Çocuğun Gelişimsel Özellikleri ve Demografik Verinin Elde Edilmesi}

Katılımc özellikleri kapsamında çocuğun eğitim aldığı okul, sınıf düzeyi ve adres bilgisi istenmiştir. Ankete katılan ebeveyn ve çocuklarının Karşıyaka ilçesinde ikamet ediyor olması ve çocukların, pandeminin başladığı süreçte (2019-2020 Eğitim Yılı) Karşıyaka ilçesi içerisinde yer alan 27 devlet ilkokulunda eğitim almış olması çalışmaya katılmak için gerekli kıstaslardır. Ankette bu iki bilgiye dair sorular yöneltilmiş, bu hususlardan farklı cevaplar veren ebeveynlerin ankete devam etmeleri, çevrimiçi anket formatı kapsamında engellenmiştir.

Anket kapsamında ebeveynlerden, çocuğun cinsiyet ve doğduğu yılı belirtmeleri istenmiştir. Çocuğun doğduğu yıl, anket uygulamasının yapıldığ yıldan çıkarılarak (2020 yılı) çocuğun yaşı elde edilmiştir. Fiziksel aktivite düzeyinde etkili olan Beden Kitle İndeksi (BKİ) değerinin hesaplanabilmesi için $\left(\mathrm{kg} / \mathrm{m}^{2}\right)$ ebeveynlerden, çocuğun anket doldurulduğu anda ölçümlenen boy $(\mathrm{cm})$ ve kilo $(\mathrm{kg})$ bilgilerinin anket formuna girmesi istenmiştir.

Çocukların fiziksel aktivite düzeyinde etkili olan demografik göstergelerin elde edilmesi için öncelikle anketi dolduran kişinin çocuğun ebeveyni olup olmadığı ile gün içinde çocuğun bakımı ile ilgilenen kişinin bilgisi sorulmuştur. Buradaki ölçüt, öncelikle çocuğun annesinin ya da babasının anketi doldurması gerekliliğidir. Gün içinde çocuğun bakımı ile ilgilenen kişinin anketi doldurması durumunda, çalışma kapsamında analizlere dahil edilebilecek bir veri olarak kabul edilmiştir. Ardından anketi dolduran katılımonın cinsiyeti 
ve doğum yılı sorulmuştur. Sosyo-demografik düzeyin belirlenmesi amacıyla TÜIKK Sosyo-Ekonomik Statü (SES) tablosu ile eşleştirilebilecek şekilde hanehalkı reisinin eğitim durumu, iş durumu ile haneye giren ortalama aylık gelir bilgisi elde edilmiştir. Hanehalkı reisinin eğitim ve iş durumu, TÜiK SES tablosu ile eşleştirilerek katılımcların SES düzeyleri (Üst-Orta-Alt SES grupları) belirlenmiştir.

\section{COVID-19 Pandemi Süreci Öncesinde ve Anketin Yapıldı̆̆ı Zaman} Aralığında Çocuğun Gerçekleştirdiği Fiziksel Aktivitenin Konumuna İlişkin Verinin Elde Edilmesi

Çalışmada elde edilmek istenen önemli bir veri de, COVID-19 pandemi süreci esnasında çocuğun fiziksel aktivite yaptığı konumları belirleyerek, bu konumların pandemi öncesine göre değişkenlik gösterip göstermediğini tespit etmektir. Bunun için üç ana zamansal süreç belirlenmiştir: (1) dışarı çıkma kısıtlamaları öncesi, (2) karantina dönemi ve (3) son 7 gün.

Ülkemizde 3 Nisan - 1 Haziran süreçlerinde, 20 yaş ve altı bireyler için sokağa çıkma yasağı getirilmiştir (Şekil 2). Bu dönem çalışmada, 'karantina dönemi' olarak adlandırılmıştır. Dolayısıyla karantina döneminin öncesi (3 Nisan 2020 öncesi), 'dışarı çıkma kısıtlamaları öncesi' dönem olarak zamansal sürece dahil edilmiştir. Çocuğun yakın zamanda gerçekleştirdiği fiziksel aktivitelerin konumunu belirlemek için ise ebeveyn tarafından anketin doldurulduğu andan itibaren 'son 7 gün', diğer bir zamansal süreç olarak tarif edilmiştir. Uluslararası Fiziksel Aktivite Değerlendirme Anketi - IPAQ (Craig vd., 2003) ve Küresel Fiziksel Aktivite Anketi - GPAQ (Armstrong ve Bull, 2006) gibi ulusal ve uluslararası çalışmalarda sıklıkla kullanılan fiziksel aktivite günlükleri/anketlerinde, kişinin fiziksel aktivite düzeyini geriye yönelik elde edebilmek için son 7 gününde gerçekleştirdiği fiziksel aktiviteler tespit edilebilmektedir. Dolayısıyla bu üç zamansal süreçte çocuğun gerçekleştirdiği fiziksel aktivitelerin konumunu tespit etmek için ebeveynlere, çoktan seçmeli bir soru ile aktivite mekanları sorulmuştur. Çalışmada kullanılan anketin nihai hali oluşturulmadan önce yapılan iki farklı pilot ankette benzer bir soru sorulmuş ve verilen cevaplar sonucunda çocukların sıklıkla fiziksel aktivite yaptıkları mekanlar listelenmiş ve nihai ankette seçilebilecek seçenekler haline getirilmiştir (Tablo 1). 


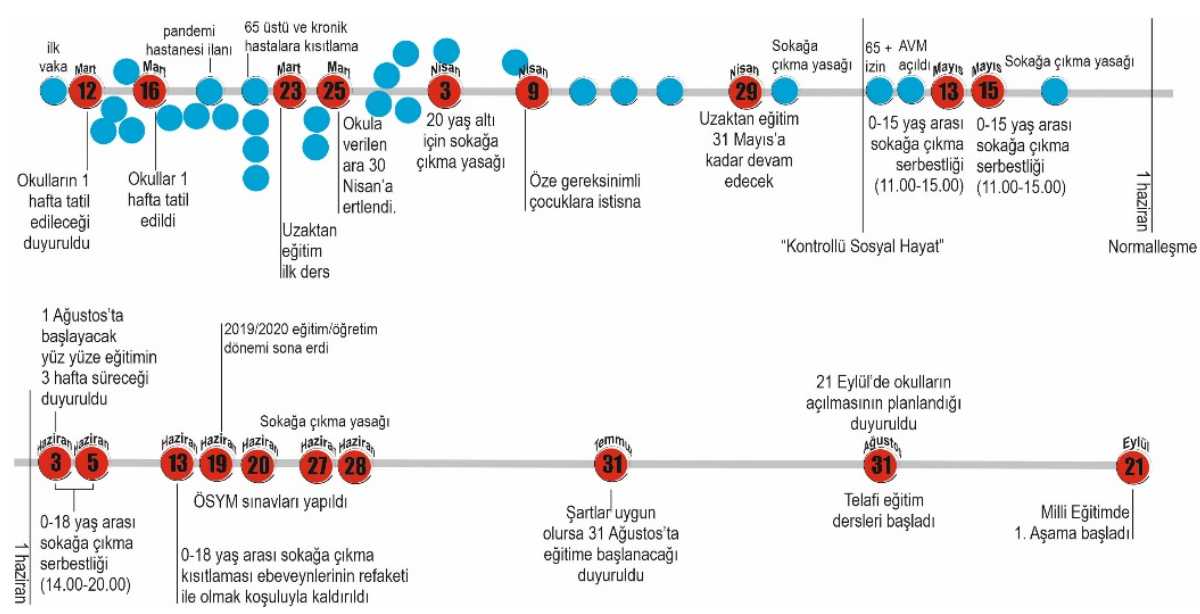

Şekil 2. Pandemi ile birlikte Türkiye'de alınan kararlar (Kırmızı renkli gösterimler, okul çağındaki çocuklar ile ilişkili kararları vurgulamaktadır)

Tablo 1. Fiziksel aktivitenin konumu

\begin{tabular}{|c|c|}
\hline Aktivite Türü & Konum \\
\hline $\begin{array}{l}\text { Yüksek şiddette fiziksel aktivite } \\
\text { (yoğun fiziksel güç gerektiren, normal solunumu } \\
\text { oldukça zorlayan, aşırı terlemeye ve yorgunluğa } \\
\text { neden olan, tek seferde en az } 15 \text { dakika süren } \\
\text { aktiviteler) }\end{array}$ & $\begin{array}{l}\text { - Evin içinde } \\
\text { - Evin bahçesinde / havuzunda } \\
\text { - Sokakta } \\
\text { - Sahil / rekreasyon alanında } \\
\text { - Çocuk parkında }\end{array}$ \\
\hline $\begin{array}{l}\text { Orta şiddette fiziksel aktivite } \\
\text { (orta düzeyde fiziksel güç gerektiren, normal } \\
\text { solunumu zorlayan, hafif terlemeye ve yorgunluğa } \\
\text { neden olan, tek seferde en az } 15 \text { dakika süren } \\
\text { aktiviteler) }\end{array}$ & $\begin{array}{l}\text { - Mahalle parkında } \\
\text { - Okul bahçesinde } \\
\text { - Kapalı spor salonunda } \\
\text { - Açık spor salonunda } \\
\text { - Alışveriş merkezinde açık alanda } \\
\text { - Alı̧veriş merkezinde kapalı alanda } \\
\text { - Hiçbir yerde }\end{array}$ \\
\hline
\end{tabular}

Kişinin amacı ve bireysel özelliklerine göre değişiklik gösteren fiziksel aktivite türleri (Frank, Engelke, ve Schmid, 2003), harcanan enerji göz önünde bulundurularak 'sedanter', 'düşük', 'orta' ve 'yükssek' şiddette fiziksel aktivite olarak sınıflandırılabilmektedir (Ainsworth vd., 2000). Çocukların sağlıklı bir gelişim için günde en az 60 dakika orta ve yüksek şiddette fiziksel aktivite yapma gereklilikleri doğrultusunda bu çalışmada, 'orta' ve 'yüksek' şiddetteki fiziksel aktivitelere odaklanılmıştır. Ebeveynlerin bu aktivite türleri arasındaki farklılığı algılayabilmeleri için yüksek şiddette fiziksel aktivite 'yoğun fiziksel güç gerektiren, normal solunumu oldukça zorlayan, aşır terlemeye ve yorgunluğa neden olan, tek seferde en az 15 dakika süren aktiviteler' olarak; orta düzeyde fiziksel aktivite 'orta düzeyde fiziksel gü̧̈ gerektiren, normal solunumu zorlayan, 
hafif terlemeye ve yorgunluğa neden olan, tek seferde en az 15 dakika süren aktiviteler' olarak tanımlanmıştır. Ebeveynlerden çocuklarının bu aktiviteleri 'çoğunlukla' hangi mekanda gerçekleştirdiğini işaretlemeleri istenmiştir.

\section{COVID-19 Pandemi Süreci Öncesinde ve Sürecinde Ebeveynlerin} Yaşadıkları Mahalleye İlişkin Algısal Değerlendirmelerinin Elde Edilmesi

Çocukların fiziksel aktivite düzeylerini ve konumlarını, fiziksel çevrenin algısal niteliklerinin etkilediği önceki bölümlerde aktarılmıştır. Bu hususta çocuğun yaşadığı mahallenin 'estetik düzeyi', 'ilgi çekiciliği', 'fiziksel aktivite olanakları', 'yeşil alanların' ve 'çocuk parklarının' niteliği, 'suç' ve 'trafik' güvenliği önemli algısal değişkenlerdir. Çalışma kapsamında yapılan ankette, ebeveynlerin mahallelerini anılan algısal değişkenler kapsamında 3'lü Likert ölçeğine göre değerlendirmeleri istenmiştir. COVID-19 pandemi sürecinin ebeveynlerde bir sağlık güvenliği algısı oluşturma durumunu belirlemek için ise mahallelerini 'temiz ve sağlıklı' olma durumuna göre değerlendirmeleri istenmiştir (Tablo 2). Bunun dışında ebeveynlerden, çocuğun fiziksel aktivite yaptığı çocuk parkları, yeşil alanlar, açık spor alanları ile kapalı alanlara ilişkin sağlık güvenliği algısına yönelik değerlendirmeler yapmaları beklenmiştir. Burada ölçüt olarak COVID-19 pandemisi ile birlikte sıklıkla vurgulanan 'temizlik (hijyen)' ve 'kalabalık olmama' kriterleri geliştirilmiştir (Tablo 2). Bu değerlendirmelerin dışarı çıkma kısıtlaması öncesi ve anketin doldurulduğu an olmak üzere iki farklı zamansal süreç kapsamında yapılması beklenmiştir.

Tablo 2. Yaşanılan mahallenin ve çocuğun aktivite yaptığı dış mekanların algısal değerlendirmeleri

\begin{tabular}{|c|c|}
\hline Mahalleye Yönelik Algısal Değişkenler & Ölçüt \\
\hline "Çocuğum için mahallemin estetik düzeyi yüksektir" & \multirow{15}{*}{$\begin{array}{l}\text { Evet } \\
\text { Kısmen } \\
\text { Hayır } \\
\text { (3 7ü Likert } \\
\text { Ölçeği) }\end{array}$} \\
\hline "Çocuğum için mahallem ilgi çekicidir" & \\
\hline $\begin{array}{l}\text { "Çocuğum için mahallemdeki fiziksel aktivite olanakları (açık ve kapalı } \\
\text { spor alanları) yeterlidir" }\end{array}$ & \\
\hline "Çocuğum için mahallemdeki yeşil alanlar yeterlidir" & \\
\hline "Çocuğum için mahallemdeki çocuk parkları yeterlidir" & \\
\hline "Çocuğum için mahallemdeki suç oranları düşüktür" & \\
\hline "Çocuğum için mahallemdeki sokaklar trafik açısından tehlike yaratmaz" & \\
\hline "Mahallem genel olarak temiz ve sağlıklıdır" & \\
\hline Aktivite Alanlarına Yönelik Algısal Değişkenler & \\
\hline "Çocuğumun aktivite yaptığı çocuk parkları temizdir" & \\
\hline "Çocuğumun aktivite yaptığı çocuk parkları kalabalık değildir" & \\
\hline "Çocuğumun aktivite yaptığı yeşil alanlar / açık spor alanları temizdir" & \\
\hline $\begin{array}{l}\text { "Çocuğumun aktivite yaptığı yeşil alanlar / açık spor alanları kalabalık } \\
\text { değildir" }\end{array}$ & \\
\hline "Çocuğumun aktivite yaptığı kapalı alanlar temizdir" & \\
\hline "Çocuğumun aktivite yaptığı kapalı alanlar kalabalık değildir" & \\
\hline
\end{tabular}


Özetle, çalışma kapsamında COVID-19 pandemisinin ortaya çıktı̆̆ dönemde Karşıyaka İlçesi içerisindeki 27 devlet ilkokulunda eğitimini tamamlayan çocukların ebeveynleri ile çevrimiçi bir anket yapılmış, çocukların pandemi öncesine göre fiziksel aktivite yaptıkları kentsel mekanlardaki değişimler belirlenmeye çalışılmış, ebeveynlerden mahallelerini pandemi öncesi ve sonrasındaki görüşlerine göre değerlendirmeleri istenmiş ve gözlemlenen değişikliklerin, pandemi temelli bir sağlık güvenliği algısını geliştirip geliştirmediği, betimsel ve çıarımsal istatistiksel yöntemler ile analiz edilmiştir. Çevrimiçi ulaştırılan anket formuna giriş yapan toplam 3225 kişinin verisi incelenmiş ve Karşıyaka ilçesinde ikamet eden, çocuğu çalışma alanındaki okullarda pandemi döneminde eğitim almış olan ve anketin tüm sorularını tamamlayan 1559 kişinin verisi, istatistiksel analizlerin yapılacağ 1 veri setini oluşturmuştur.

\section{Katılımcilar}

2019-2020 Eğitim Y1lı içinde Karşıyaka ilçesindeki 27 devlet okulunda eğitim alan toplam öğrenci sayısı 12366'dir. Dolayısıyla çalışma Karşıyaka ilçesindeki ilkokullarda eğitim alan öğrenci sayısının \%12,6'sına ulaştğından geniş bir temsiliyete sahiptir. Çocukların \%28,1'i 1. sınfl, \%26'sı 2. sınıfl, \%31,9'u 3. sınıfı ve \%14'ü 4. sınıfı tamamlamıştır. 4. sınıfı tamamlayan çocukların oranının düşük olmasının nedeni, anketin yapıldığı dönemde (Ağustos-Eylül) okulların kapanmış olması nedeniyle öğrencilerin ilkokuldan mezun olmaları ve sınıf öğretmenleri ile iletişim olanaklarının azalmasıdır.

Katılımcıların \%45,5'i ilçenin ana ulaşım güzergahlarına yakın ve nüfus büyüklüğü olarak da yoğun olan mahallelerinde (Yall, Demirköprü, Goncalar, Nergis, Bahriye Üçok, Bahçelievler, Bahariye, Dedebaşı, Fikri Altay, Şemikler Mahalleleri); \%37,7'si ilçenin kuzeyinde yer alan, ana taşıt aksına (çevreyolu) yakın ve yeni yerleşim alanları, kapalı siteler, dönüşüm alanları gibi birbirinden farklı mekansal yapılar gösteren mahallelerinde (Cumhuriyet, Örnekköy, İmbatlı, İnönü, Mustafa Kemal, Zübeyde Hanım, Latife Hanım Mahalleleri) ikamet etmektedir. Katılımciların \%16,8'i ise ilçenin sahil bandında yer alan mahallelerde (Mavişehir, Atakent, Bostanlı, Aksoy, Donanmacl, Tuna, Alaybey, Tersane mahalleleri) ikamet etmektedir. Mahalleler bazındaki bu farklılık, Türkiye İstatistik Kurumu (TÜİK) İzmir Bölge Müdürlüğü'nden alınan 2019 yılı Adrese Dayalı Nüfus Kayıt Sistemi (ADNKS) mahalle bazında yaş verilerine göre, ilkokul çağındaki çocuk nüfusunun farklı mahallelere dağılması nedeniyledir. 
Çalışmaya 1460 anne, 97 baba ve ebeveyn dışında çocuğun gün içindeki bakımı ile ilgilenen 2 farklı (kadın) akraba katılmıştır. Katılımcıların yaşları ortalama 38,28'dir (Min=20, Maks=60, SD=5,274). Anketi dolduran erkeklerin yaş ortalaması (Ort=41,94; Min=20, Maks=60, $S D=6,25)$, kadınların yaş ortalamasından (Ort=38,03, Min=20, Maks=56, SD=5,12) fazladır. Katılımcların iş, eğitim ve gelir durumu ile sosyo-ekonomik statü (SES) durumların içeren demografik göstergeleri Tablo 3'teki gibidir. Buna göre katılımcıların \%48'i orta, \%38,2'si ise üst SES grubundadır. Katılımciların yalnızca \%13,8'i alt SES grubundadır. Dolayısıyla veri, orta ve üst SES gruplarının ağırlıklı olduğu bir dağılım sergilemektedir.

Ankete katılan ebeveynlerin çocuklarının gelişimsel özellikleri incelendiğinde, çalışmaya 812 erkek (\%52), 747 kı (\%48) öğrencinin katıldığı, ortalama yaşın 8,39 olduğu (Min=6, Maks=11, SD=1,09) gözlemlenmiştir. Cinsiyete göre yaş ortalamaları benzerdir (Erkek=8,39, SD=1,07; Kız=8,39, SD=1,11). Katılımcı çocukların cinsiyet ve yaş ortalamaları arasında, sonuçları etkileyebilecek düzeyde istatistiksel açıdan anlamlı bir farklılık bulunmamıştır ( $t=-0,084$, $\mathrm{df}=1557$, $\mathrm{p}=0$,933). Katılımc çocukların gelişimsel özelliklerini belirlemek için boy ve kilo bilgilerinden Beden Kitle İndeksleri (BKI) hesaplanmıştır. Erkek çocuklar (Ort=18,26, SD=4,86) ile kız çocukların (Ort=17,91; SD=3,68) BKİ değerleri arasında, istatistiksel açıdan anlamlı bir farklılık bulunmamaktadır $(t=1,613 ; d f=1557 ; p=0,107)$. Dolayısıyla, cinsiyet ve yaş değişkenlerinde olduğu gibi, BKİ değişkeninde de katılımcı çocuklar arasında benzer bir dağılım söz konusudur. Dolayısıyla, çalışmaya katılan ebeveynler ve çocuklar, farklı nitelikler gösteren mahallelerde oturan, çoğunlukla üst ve orta SES grubuna dahil ailelerden gelmektedir. Katılımc çocukların gelişimsel ve demografik verileri ise benzer bir dağılım sergilemektedir. 
Tablo 3. Katılımciların demografik göstergeleri

\begin{tabular}{|c|c|c|c|}
\hline \multicolumn{2}{|c|}{ Hanehalkı Reisinin İș Durumu } & \multirow{2}{*}{$\begin{array}{l}\mathbf{N} \\
92\end{array}$} & \multirow{2}{*}{$\begin{array}{c}\% \\
\% 5,9\end{array}$} \\
\hline \multirow{3}{*}{ Çalışmayan } & Ev Kadını & & \\
\hline & Emekli & 98 & $\% 6,3$ \\
\hline & Geçici İşsiz & 120 & $\% 7,7$ \\
\hline \multirow{7}{*}{$\begin{array}{l}\text { Kendi } \\
\text { Hesabına } \\
\text { Çalışan }\end{array}$} & Nitelikli serbest meslek sahibi & 265 & $\% 17$ \\
\hline & $0-5$ çalışanlı tüccar & 60 & $\% 3,8$ \\
\hline & 6-20 çalışanlı tüccar & 16 & $\% 1,0$ \\
\hline & $20+$ çalışanlı tüccar & 7 & $\% 0,4$ \\
\hline & 1-9 çalışanlı şirket / imalathane sahibi & 25 & $\% 1,6$ \\
\hline & 10-25 çalışanlı şirket / imalathane sahibi & 3 & $\% 0,2$ \\
\hline & $25+$ çalışanlı şirket / imalathane sahibi & 8 & $\% 0,5$ \\
\hline \multirow{6}{*}{$\begin{array}{l}\text { Ücretli } \\
\text { Çalışan }\end{array}$} & Üst düzey yönetici & 62 & $\% 4,0$ \\
\hline & 10'dan az çalışanlı orta düzey yönetici & 53 & $\% 3,4$ \\
\hline & 10'dan fazla çalışanlı orta düzey yönetici & 95 & $\% 6,1$ \\
\hline & Nitelikli uzman, mühendis, teknik eleman & 143 & $\% 9,2$ \\
\hline & Memur / ofis çalışanı & 226 & $\% 14,5$ \\
\hline & İşçi / hizmetli & 286 & $\% 18,3$ \\
\hline \multicolumn{2}{|c|}{ Hanehalkı Reisinin Eğitim Durumu } & $\mathbf{N}$ & $\%$ \\
\hline \multicolumn{2}{|c|}{ Okuma / yazma bilmiyor } & 4 & $\% 0,3$ \\
\hline \multicolumn{2}{|c|}{ Okuma / yazma biliyor } & 7 & $\% 0,4$ \\
\hline \multicolumn{2}{|c|}{ İlkokul mezunu } & 194 & $\% 12,4$ \\
\hline \multicolumn{2}{|c|}{ Ortaokul mezunu } & 180 & $\% 11,5$ \\
\hline \multicolumn{2}{|c|}{ Lise mezunu } & 532 & $\% 34,1$ \\
\hline \multicolumn{2}{|c|}{ Üniversite mezunu } & 579 & $\% 37,1$ \\
\hline \multicolumn{2}{|c|}{ Lisansüstü mezunu } & 63 & $\% 4,0$ \\
\hline \multicolumn{2}{|c|}{ Hanehalkı Ortalama Aylık Gelir Durumu } & $\mathbf{N}$ & $\%$ \\
\hline \multicolumn{2}{|c|}{2.500 TL ve alt1 } & 370 & $\% 23,7$ \\
\hline \multicolumn{2}{|c|}{$2.501 \mathrm{TL}-5.000 \mathrm{TL}$} & 651 & $\% 41,8$ \\
\hline \multicolumn{2}{|c|}{$5.001 \mathrm{TL}-7.500 \mathrm{TL}$} & 298 & $\% 19,1$ \\
\hline \multicolumn{2}{|c|}{$7.501 \mathrm{TL}-10.000 \mathrm{TL}$} & 148 & $\% 9,5$ \\
\hline \multicolumn{2}{|c|}{10.000 TL üstü } & 92 & $\% 4,0$ \\
\hline \multicolumn{2}{|c|}{ Sosyo-Ekonomik Statü (SES) } & $\mathbf{N}$ & $\%$ \\
\hline Üst & $(A-B)$ & 595 & $\% 38,2$ \\
\hline Orta & $(\mathrm{C} 1-\mathrm{C} 2)$ & 749 & $\% 48,0$ \\
\hline Alt & $(\mathrm{D}-\mathrm{E})$ & 215 & $\% 13,8$ \\
\hline
\end{tabular}

\section{Bulgular}

Çalışma kapsamında yapılan betimsel ve çıkarımsal istatistik sonuçları, pandemi temelli zamansal süreç bağlamında (1) fiziksel aktivite mekanındaki değişim, (2) ebeveynin mahalle algısındaki değişim ve sağlık güvenliği algısının oluşumu başlıkları üzerinden tartışılmıştır. 


\section{COVID-19 Pandemisi Öncesi ve Sonrası Süreçte Çocukların Fiziksel Akti- vitelerini Gerçekleştirdikleri Mekanlar}

Çalışma kapsamında fiziksel aktivite orta şiddette ve yüksek şiddette olarak ayrıştırılmış ve ebeveynlerden, dışarı çıkma kısıtlamaları öncesi ve anketi doldurdukları andan itibaren son 7 gün içerisinde çocuklarının hangi mekanlarda bu aktiviteleri çoğunlukla gerçekleştirdiklerini işaretlemeleri istenmiştir. Tablo 4, katılımcı ebeveynlerin çocuklarının fiziksel aktivite mekanındaki değişimleri göstermektedir.

Tablo 4. Dışarı çıkma kısıtlamaları öncesi ve anket doldurulduğu andan itibaren son 7 gün içerisinde çocukların orta ve yüksek şiddette fiziksel aktivitelerini gerçekleştirdikleri mekanlar

\begin{tabular}{|c|c|c|}
\hline Aktivite Mekanlanı & $\begin{array}{c}\text { Dışarıya çıkma } \\
\text { kısıtlamaları öncesi }\end{array}$ & $\begin{array}{c}\text { Son } 7 \text { gün } \\
\text { (Ağustos-Eylül) }\end{array}$ \\
\hline \multicolumn{3}{|c|}{ Orta Şiddette Fiziksel Aktivite } \\
\hline Evin içinde & $\% 9.1$ & $\% 24.0$ \\
\hline Evin bahçesinde / havuzda & $\% 7.1 \%$ & $\% 18.5$ \\
\hline Sokakta & $\% 13.6$ & $\% 14.4$ \\
\hline Sahil / rekreasyon alanında & $\% 6.2$ & $\% 12.1$ \\
\hline Çocuk parkında & $\% 20.6$ & $\% 7.8$ \\
\hline Mahalle parkında & $\% 8.6$ & $\% 6.5$ \\
\hline Okul bahçesinde & $\% 14.7$ & $\% 1.4$ \\
\hline Kapalı spor salonunda & $\% 8.1$ & $\% 0.8$ \\
\hline Açık spor alanlarında & $\% 6.2$ & $\% 3.5$ \\
\hline Alışveriş merkezinde açık alanda & $\% 0.7$ & $\% 0.0$ \\
\hline Alışveriş merkezinde kapalı alanda & $\% 0.5$ & $\% 0.0$ \\
\hline Diğer & $\% 2.1$ & $\% 4.6$ \\
\hline Hiçbir yerde & $\% 2.5$ & $\% 6.5$ \\
\hline \multicolumn{3}{|c|}{ Yüksek Şiddette Fiziksel Aktivite } \\
\hline Evin içinde & $\% 6.2$ & $\% 21.9$ \\
\hline Evin bahçesinde / havuzda & $\% 6.8$ & $\% 17.0$ \\
\hline Sokakta & $\% 11.6$ & $\% 13.7$ \\
\hline Sahil / rekreasyon alanunda & $\% 5.2$ & $\% 11.5$ \\
\hline Çocuk parkında & $\% 21.2$ & $\% 7.1$ \\
\hline Mahalle parkında & $\% 6.5$ & $\% 6.3$ \\
\hline Okul bahçesinde & $\% 12.3$ & $\% 1.4$ \\
\hline Kapalı spor salonunda & $\% 13.6$ & $\% 1.0$ \\
\hline Açık spor alanlarında & $\% 8.5$ & $\% 3.6$ \\
\hline Alışveriş merkezinde açık alanda & $\% 0.3$ & $\% 0.0$ \\
\hline Alışveriş merkezinde kapalı alanda & $\% 0.4$ & $\% 0.0$ \\
\hline Diğer & $\% 2.2$ & $\% 5.6$ \\
\hline Hiçbir yerde & $\% 5.1$ & $\% 10.7$ \\
\hline
\end{tabular}

Tablo 4'e göre pandemi sonrasındaki süreçte çocukların hem orta hem de yüksek şiddette fiziksel aktiviteyi gerçekleştirmek için çoğunlukla konutta ya 
da konutun bahçesinde/havuzunda bulundukları, geniş açk alanlar olan sahil ve rekreasyon alanların tercih ettikleri görülmektedir. Fiziksel aktivite için çocuk parklarının, mahalle parklarının, okul bahçesinin, kapalı ve açık spor alanlarının, alışveriş merkezlerindeki kapalı ve açik mekanların tercihlerinde düşüşler gözlemlenmiştir. Burada dikkat çekici bir sonuç da, çocuğun sağlıklı gelişimi için gerçekleştirmesi gereken orta ve yüksek şiddette fiziksel aktivite oranlarında düşüşün yaşanmasıdır. Dışarı çıkma kısıtlamaları öncesinde fiziksel aktiviteyi hiçbir yerde gerçekleştirmeyen çocukların oranı, pandemi sonrasında dikkate değer bir artış göstermiştir. Betimsel analizler ile gözlemlenen bu farklılık çıkarımsal istatistiksel analizlerle incelendiğinde hem orta şiddette fiziksel aktivitenin $\left(X^{2}=2464,097 ; \mathrm{df}=12 ; \mathrm{p}=0,000\right)$ hem de yüksek şiddette fiziksel aktivitenin $\left(X^{2}=1862,649, \mathrm{df}=12, \mathrm{p}=0,000\right)$ gerçekleştiği mekânların, dışarı çıkma kısıtlaması öncesine göre farklılık gösterdiği görülmüştür.

\section{COVID-19 Pandemisi Öncesi ve Sonrası Süreçte Ebeveynlerin Mahalle Algılarındaki Değişim ve Mahalleye Yönelik Sağlık Güvenliği Algısı}

Çalışma kapsamında ebeveynlerin mahallelerine yönelik algısal değerlendirmelerindeki farklılıklar incelenmiştir (Tablo 5). COVID-19 pandemisi öncesinde bilimsel yazında çocuğun fiziksel aktivite düzeyini etkilediği ileri sürülen fiziksel çevrenin estetik ve ilgi çekicilik düzeyi, suç ve trafik güvenliği ile yeşil alanların yeterliliğine ilişkin değişkenlerin, pandemi öncesi döneme göre olumsuz yönde değiştiği izlense de bu değişim istatistiksel açıdan anlamlı bulunmamıştır. Buna karşın, çocuk parkları ve mahalledeki aktivite olanaklarının yeterliliğine ilişkin görüşlerdeki değişim istatistiksel açıdan anlamlı bulunmuştur. Sonuçlar pandemi süreci ile birlikte ebeveynlerin, mahallelerindeki çocuk parklarını ve fiziksel aktivite olanaklarını, yetersiz bulduğunu göstermektedir. 
Tablo 5. Dışarı çıkma kısıtlamaları öncesi ve anket doldurulduğu andan itibaren son 7 gün içerisinde ebeveynlerin mahallelerine yönelik algısındaki değişimler

\begin{tabular}{|c|c|c|c|}
\hline $\begin{array}{l}\text { Algısal } \\
\text { Değerlendirme } \\
\text { Ölçütleri }\end{array}$ & $\begin{array}{l}\text { Dişarıya çıkma } \\
\text { kısıtlamaları } \\
\text { öncesi }\end{array}$ & $\begin{array}{l}\text { Son } 7 \text { gün } \\
\text { (Ağustos-Eylül) }\end{array}$ & $\begin{array}{l}\text { Çıkarımsal } \\
\text { İstatistik } \\
\text { Sonuçları }\end{array}$ \\
\hline \multirow[t]{3}{*}{ Estetik } & Evet $=\% 26,8$ & Evet=\%24,4 & \\
\hline & K1smen=\%37,7 & Kismen=\%36,8 & * \\
\hline & Hayır $=\% 35,5$ & Hayır $=\% 38,8$ & \\
\hline \multirow[t]{3}{*}{ İlgi çekici } & Evet=\%28,3 & Evet $=\% 25,2$ & \\
\hline & Kismen=\%34,4 & Kismen $=\% 34,0$ & * \\
\hline & Hayır= \%37,3 & Hayır $=\% 40,8$ & \\
\hline \multirow[t]{3}{*}{ Yeşil alanlar yeterli } & Evet=\%24,8 & Evet $=\% 22,4$ & \\
\hline & Kismen $=\% 22,8$ & Kismen=\%21,8 & * \\
\hline & Hayır $=\% 52,3$ & Hayır $=\% 55,8$ & \\
\hline \multirow[t]{3}{*}{ Suç oranı düşük } & Evet=\%67,1 & Evet $=\% 64,0$ & \\
\hline & Kismen=\%23,4 & Kısmen=\%25,5 & * \\
\hline & Hayır $=\% 9,4$ & Hayır=\%10,5 & \\
\hline \multirow[t]{3}{*}{ Trafik tehlikesi yok } & Evet $=\% 26,9$ & Evet $=\% 26,4$ & \\
\hline & Kismen=\%35,8 & Kismen=\%35,4 & * \\
\hline & Hayır=\%37,3 & Hayır=\%38,3 & \\
\hline \multirow[t]{3}{*}{ Çocuk parkları yeterli } & Evet $=\% 39,0$ & Evet $=\% 33,5$ & $X^{2}=13,776, d f=2$, \\
\hline & Kısmen=\%24,4 & Kismen=\%23,7 & $\mathrm{p}=0,001$ \\
\hline & Hayır $=\% 36,6$ & Hayır $=\% 42,7$ & \\
\hline \multirow{3}{*}{$\begin{array}{l}\text { Fiziksel aktivite } \\
\text { olanakları yeterli }\end{array}$} & Evet $=\% 20$ & Evet $=\% 15,9$ & $X^{2}=10,650, d f=2$, \\
\hline & Kismen=\%23,5 & Kismen=\%22,5 & $\mathrm{p}=0,005$ \\
\hline & Hayır $=\% 56,6$ & Hayır=\%61,6 & \\
\hline \multirow[t]{3}{*}{ Temiz ve sağlıklı } & Evet $=\% 42,5$ & Evet $=\% 38,9$ & $X^{2}=8,365, \mathrm{df}=2$ \\
\hline & Kısmen=\%40,4 & Kismen $=\% 40,2$ & $\mathrm{p}=0,015$ \\
\hline & Hayır=\%17,1 & Hayır $=\% 20,9$ & \\
\hline
\end{tabular}

* Farklılık, istatistiksel açıdan anlamlı bulunmamıştır

Tablo 5'te gözlemlenen önemli bir başka sonuç ise ebeveynlerin mahallelerini genel olarak temiz ve sağlıklı olarak değerlendirmelerinin, pandemi öncesi döneme göre olumsuz yönde değişkenlik göstermesidir. İstatistiksel açıdan anlamlı bulunan bu değişiklik mahalleye yönelik sağlık güvenliği algısının oluştuğuna ilişkin ipuçları barındırmaktadır. Böylesi bir algının, çocuğun mahallede fiziksel aktivite yaptı̆̆ mekanlara yönelik olarak gelişip gelişmediğine ilişkin sonuçlar Tablo 6'daki gibidir. Buna göre ebeveynler pandemi öncesine göre çocuk parklarını, yeşil alanlar ve açk spor alanları ile çocuğun aktivite yaptığı kapalı alanları temiz (hijyenik) bulmamaktadır. Dolayısıyla bu sonuç, ebeveynlerin çocuklarını aktivite yapmaları için yönlendireceği mekanlarda temizliğin önemli bir kıstasa dönüşeceğini gösterebilir. Aynı tabloda dikkat çeken bir diğer sonuç ise, istatistiksel açıdan anlamlı bulunan çocuk parklarının kalabalıklığına ilişkin değişimdir. Pandemi öncesine göre çocuk parklarının kalabalık olmadığına ilişkin değerlendirmede artış bulunmaktadır. Bu sonuç, sokağa çıkma kısıtlamalarının olması, kişilerin çocuk parklarını 
daha az tercih ediyor olması gibi durumlardan kaynaklanabilir. Kaldı ki çalışmanın sonuçları da çocukların fiziksel aktivite için pandemi öncesine göre daha az oranda çocuk parklarını tercih ettiğini göstermiştir (Tablo 4). Bu durum, mahalleler genelinde çocuk parklarına ilişkin olumsuz bir sağlık güvenliği algısı oluştuğuna dair bir yorumda bulunmayı gerektirebilir.

Tablo 6. Dışarı çıkma kısıtlamaları öncesi ve anket doldurulduğu andan itibaren son 7 gün içerisinde ebeveynlerin, çocuklarının mahallelerinde fiziksel aktivite yaptıkları mekanlara ilişkin sağlık güvenliği algısı

\begin{tabular}{|c|c|c|c|}
\hline $\begin{array}{l}\text { Sağlık Güvenliği } \\
\text { Algısı Ölçütleri }\end{array}$ & $\begin{array}{c}\text { Dışarıya çıkma } \\
\text { kısıtlamaları } \\
\text { öncesi }\end{array}$ & $\begin{array}{c}\text { Anketin } \\
\text { cevaplandığı } \\
\text { dönem } \\
\text { (Ağustos-Eylül) }\end{array}$ & $\begin{array}{c}\text { Çıkarımsal } \\
\text { İstatistik } \\
\text { Sonuçları }\end{array}$ \\
\hline Çocuk parkları temiz & $\begin{array}{l}\text { Evet \%25,7 } \\
\text { Kismen \%42,9 } \\
\text { Hayır \%31,4 }\end{array}$ & $\begin{array}{l}\text { Evet \%22,7 } \\
\text { Kismen \%41,3 } \\
\text { Hayır \%36,1 }\end{array}$ & $\begin{array}{l}X^{2}=8,298, d f=2, \\
p=0,016\end{array}$ \\
\hline $\begin{array}{l}\text { Çocuk parkları } \\
\text { kalabalık değil }\end{array}$ & $\begin{array}{l}\text { Evet \%19,0 } \\
\text { Kismen \%30,7 } \\
\text { Hayır \%50,3 }\end{array}$ & $\begin{array}{l}\text { Evet \%20,8 } \\
\text { Kısmen \%33,4 } \\
\text { Hayır \%45,8 }\end{array}$ & $\begin{array}{l}X^{2}=6,114, d f=2, \\
p=0,047\end{array}$ \\
\hline $\begin{array}{l}\text { Yeşil alanlar / açık } \\
\text { spor alanları temiz }\end{array}$ & $\begin{array}{l}\text { Evet \%27,6 } \\
\text { Kismen \%45,9 } \\
\text { Hayır \%26,6 } \\
\end{array}$ & $\begin{array}{l}\text { Evet \%24,6 } \\
\text { Kısmen \%44,33 } \\
\text { Hayır \%31,1 } \\
\end{array}$ & $\begin{array}{l}X^{2}=8,304, d f=2, \\
p=0,016\end{array}$ \\
\hline $\begin{array}{l}\text { Yeşil alanlar / açık } \\
\text { spor alanları } \\
\text { kalabalık değil }\end{array}$ & $\begin{array}{l}\text { Evet \%19,2 } \\
\text { Kısmen \%35,7 } \\
\text { Hayır \%45,1 }\end{array}$ & $\begin{array}{l}\text { Evet \%20,7 } \\
\text { Kısmen \%36,1 } \\
\text { Hayır \%43,2 }\end{array}$ & * \\
\hline Kapalı alanlar temiz & $\begin{array}{l}\text { Evet \% 28,8 } \\
\text { Kismen \% 45,1 } \\
\text { Hayır \% 26,1 }\end{array}$ & $\begin{array}{l}\text { Evet \% 26,6 } \\
\text { Kismen \% } 42 \\
\text { Hayır \% 31,4 } \\
\end{array}$ & $\begin{array}{l}X^{2}=10,168, d f=2 \\
p=0,006\end{array}$ \\
\hline $\begin{array}{l}\text { Kapalı alanlar } \\
\text { kalabalık değil }\end{array}$ & $\begin{array}{l}\text { Evet \%21,5 } \\
\text { Kismen \%34,2 } \\
\text { Hayır \%44,3 }\end{array}$ & $\begin{array}{l}\text { Evet \%23,2 } \\
\text { Kismen \%34,1 } \\
\text { Hayır \%42,7 }\end{array}$ & * \\
\hline
\end{tabular}

\section{Tartışma ve Sonuç}

Epidemiyolojik veriler doğrultusunda dünya genelinde çocuklarda hızlı bir ivmeyle artan obezite prevelansının karşısında önemli bir araç olarak çocukların fiziksel aktivite düzeylerinin arttırlması gerektiği savunulmaktadır (WHO, 2016). DSÖ çocuklarda hem kas-iskelet sistemi hem de temel zihinsel, motor ve sosyal becerilerin gelişimi için özellikle de orta ve yüksek şiddetteki fiziksel aktivitenin arttırılması gerektiğini, bunun için ise kentsel mekanların aktif ulaşım türelleri ile desteklenmesi, emniyetli aktif oyun ve dinlenme olanakları sağlanması gibi düzenlemelerin yapması gerekliliğini vurgulanmaktadır (WHO, 2016). Buna paralel olarak, DSÖ'nün 'Herkes için Sağlik' ilkesinin, yerel düzeyde uygulanabilmesi için başlattığı Sağlıkı Kentler Projesi'nin 
7. Fazında (WHO, 2019) fiziksel aktivite düzeyini arttıracak sağlıklı kentsel mekanların tasarlanması ve planlanması öncelenmektedir. Özellikle çocukların sağlıklarını geliştirmek için günde 60 dakika orta ve yüksek şiddette fiziksel aktivite yapma gerekliliği ve bu gerekliliğe ulaşmada dış mekanda geçirilen zamanın önemine ilişkin vurgu göz önünde bulundurulduğunda, kentlerin aktiviteyi teşvik edecek biçimde tasarlanması oldukça büyük bir önem kazanmaktadır.

Ancak yaşadığımız süreçte, COVID-19 salgınıyla mücadele kapsamında alınan önlemler, dış mekanda geçirilen süreyi azaltmak ya da doğrudan mekanla etkileşimi kesmek üzerinedir. Dolayısıyla, pandemi ile mücadelede alınan önlemler gerekli olmakla birlikte, çocukların fiziksel aktivite düzeylerini olumsuz yönde etkileyen bir faktöre dönüşebileceği göz önünde bulundurulmadır. Pandemi ile mücadelenin başarılacağı gelecek zamanda, kişilerin kentsel mekana ilişkin kaygı yaşamaları ve hem tüm bireylerin hem de özellikle çocukların (ve ebeveynlerin) kentsel mekana ilişkin olumsuz algılarının yaratabileceği problemler ise henüz bilinmemektedir. Bu durum, çocuklar ve ebeveynleri özelinde bir sağlık güvenliği algısı yaratabilecek ve kentsel mekanla etkileşime girme istekliliğini etkileyebilecek bir faktör olarak değerlendirilmelidir. Bu çalışma, çocukların fiziksel aktivite için tercih ettikleri kentsel mekanlarda pandemi temelli bir değişimi sorguladığı ve bu değişimin bir sağlık güvenliği algısı nedeniyle oluşup oluşmadığını belirlemeye çalışması açısından literatüre önemli bir katkı sağlayacaktır.

Çalışmada elde edilen sonuçlar fiziksel aktivite yapılan mekanların pandemi öncesi döneme göre farklılıklar içerdiğini göstermektedir. Çocuklar daha çok ev ortamında fiziksel aktivite yapmakta, pandemi öncesinde etkileşimde olduğu kentsel mekanlarda ise aktivite yapmayı tercih etmemektedir. Oysa ki pandemi öncesi bilimsel yazında çocukların orta ve yüksek şiddette fiziksel aktivite için daha çok dış mekanları tercih ettiği (Çetintahra, 2015), çocuk oyun alanlarının ve açık spor alanları gibi fiziksel aktivite olanaklarının (Brodersen, vd, 2005) yeterliliğinin çocuğun aktivite düzeyini artıran unsurlar olduğu belirtilmektedir. Dolayısıyla söz konusu mekanlardan kısıtlanmanın, çocuğun aktivite düzeyini azaltacak ve sağlığını olumsuz etkileyecek bir sonuca neden olabileceği görülmektedir.

Pandemi ile mücadele kapsamında alınan dış mekan kısıtlama kararları dışında, ebeveynin çocuğu diş mekanda aktiviteye teşvik etmesi (ya da etmemesi) de kritik bir durum oluşturmaktadır. Pandemi öncesi yazında sıklıkla vurgulandığı gibi ebeveyn, çocuğun aktivite düzeyi ve aktivite mekanı tercihinde etkili bir faktördür (Kail, 2002; Thorleifsdottir, 2008). Bu çalışmanın 
sonucunda da ebeveynlerin yaşadıkları mahalleye ve çocuklarının aktivite yaptıkları mekanlara ilişkin "temizlik ve sağlıklılık" açısından olumsuz değerlendirmelerinin, çocuğu dış mekanda aktiviteye yönlendirme düzeyinde etkili olabileceğine dair ipuçları yakalanmıştır. Bu ise pandemi temelli bir sağlık güvenliği algısının geliştiğini, bu algının ise söz konusu mekanların "temizlik" kriteri bağlamında oluştuğunu göstermektedir.

Pandemi öncesi bilimsel yazında çocuğun fiziksel aktivite düzeyinde ve konumunda etkili bulunan fiziksel çevrenin algısal niteliklerinin, pandemi sonrası aktivite mekanı tercihinde istatistiksel açıdan anlamlı bir değişime neden olmadığı, aktivite mekanlarının daha çok sağlık güvenliği algısı üzerinden değerlendirildiği izlenmiştir. Bu durum, ileriki dönemde fiziksel aktivite mekanının niteliklerinin değerlendirildiği anket çalışmalarında, sokak değerlendirme araçlarında ve mekansal gözlemlere dayalı çalışmalarda 'sağlık güvenliği algısı' kriterinin de göz önünde bulundurulmasını gerekli göstermektedir.

Çalışmanın sonuçlarından birisi de orta ve yüksek şiddette fiziksel aktivite yapmayan çocukların, pandemi öncesine göre artış göstermesidir. Dolayısıyla hem kentsel mekanla etkileşime girmede hem de fiziksel aktivite gerekliliklerini karşılamada, pandemi sonrası ciddi bir azalma gözlemlendiğinden, bu durumun çocuklar açısından önemli sağlık sorunlarına neden olabileceğine dikkat çekilmelidir. Bu nedenle, pandemi ile mücadele sonrasında ebeveynlerin ve çocukların kentsel mekanı sağlık açısından olumlu olarak algilaması ve fiziksel aktiviteye yönlenmesini sağlayacak önlemler alınması zorunlu görülmektedir. Burada, kentsel mekandaki sağlık güvenliği algısının ne tür fiziksel çevre özellikleri ile oluştuğunu belirlemek de önemli olacaktır. İleriki çalışmalarda, sağlık güvenliği algısının kentsel tasarım ölçeğindeki hangi mikro fiziksel çevre nitelikleri ile ilişkili olduğunun belirlenmesi, hem literatüre hem de yerel yönetimlerin önlemlerini geliştirmesi açısından uygulama alanına katkı koyacaktır. 


\section{Extended Abstract}

\section{Parents' Perception of Neighborhood's Health Safety: An Investigation in Karsiyaka for Pre and Post COVID-19 Outbreak}

Gözde Ekşioğlu Çetintahra
Senem Tezcan

ORCID: 0000-0001-9746-495X ORCID: 0000-0003-0532-8825ＯRCID: 0000-0003-2009-0763

Bedriye Çınar

Within the scope of combating the new coronavirus epidemic, which was declared as pandemic by the World Health Organization (WHO) on March 11, 2020, it was necessary to take a series of arrangements to change the usual order of urban life. The most effective and preferred one was the restrictions of urban open space. In Turkey, schools and universities were closed as of March 16, 2020, and a curfew was imposed for individuals aged 20 and under between April 3 - June 1, 2020. Therefore, this age group could not leave their homes for a while and was isolated from urban open spaces. Undoubtedly, these arrangements are necessary in combating the pandemic. However, it should be kept in mind that children in the developmental age who stay indoors for a long time may face sociological, psychological and physical problems in the future. One of these problems is that the obesity prevalence in children may increase due to decrease in physical activity. In order to reduce the obesity prevalence, it's been often required in the prepandemic literature that children's activity levels must be increased and in order to meet the physical activity requirements they must be directed to urban open areas. However, the restrictions imposed with the COVID-19 outbreak make it difficult to meet these requirements.

Beside the open space restrictions applied today, when returning to normal life, the willingness of the parents to direct their children to outdoor physical activities should also be taken into consideration. At this point, it will be necessary to determine the parents' health safety perception against the physical activity opportunities for urban space. Therefore, in this study, it was aimed to determine the changes in the physical activity place prefer- 
ence of 6 to 11 year-old children compared to the periods before and after Covid-19 pandemic.

In this study, an online survey was conducted with the parents of 1559 children who were educated during the pandemic process in 27 state primary schools in Karşıyaka District of İzmir Province. The online survey was conducted during the months of August and September, 2020. The parents were asked about the socio-demographic situation, the developmental characteristics of their children, and the locations that children meet moderate and vigorous physical activities before and after Covid-19. In addition, parents were asked about their perceptual evaluation of their neighborhoods based on their views before Covid-19 and during the process. For perceptual evaluations, parents were asked to evaluate the aesthetic level, traffic and crime safety, the adequacy of physical activity opportunities, green areas, playgrounds of their neighborhood. They were asked to evaluate the "cleanliness" and "crowdedness" of the green areas, playgrounds and closed areas where their children do physical activity in relation to the perception of health safety of the neighborhood. Participant parents' $48 \%$ were included intermediate and $38.2 \%$ were included high level socio-economic status groups. Participant children were $52 \%$ boys and $48 \%$ girls. The average age of the children was 8.39 and showed a similar range according to gender. The average BMI of children was 18.26 for boys and 17.91 for girls, and the BMI variance was similar in terms of gender.

The results were analyzed in two stages: (1) the change in the physical activity place according to Covid-19 process, (2) the change in the neighborhood perception of parents. The results showed that children's physical activity places have changed after the emergence of the Covid-19 pandemic. Accordingly, children are now physically active in the house, in the garden, and in large open green areas. While children were doing physical activity in playgrounds, indoor and outdoor sports areas before Covid-19, activities in these areas decreased with the emergence of the Covid-19 pandemic. The relationship between this change that occurred with the Covid-19 pandemic and the perceptual evaluations of the parents for their neighborhood was statistically analyzed. Accordingly, the aesthetic level, traffic and crime safety of the neighborhood, which was claimed to be effective in the child's physical activity levels in the scientific literature before the pandemic, were not found to be statistically significant with the change in the physical activity levels. On the other hand, it has been observed that the perception of inadequacy of playgrounds and activities in the neighborhood is related to the 
child's physical activity space. An important result was observed in the variables related to the health safety perception of the neighborhood. By that of, parents do not find the playgrounds, green areas, open sports areas and closed areas where their children do activities clean anymore. This situation contains clues that there is a negative perception of health safety in terms of "cleaning" criteria for the places where the child does physical activity. The statistically significant relationship between the perception of health safety and the places where the child does physical activity suggests that the perception of health safety may create an obstacle to the child's outdoor physical activity.

All results draw attention that when the fight against the Covid-19 pandemic is completed, if the parents' negative perception of health safety regarding their neighborhoods and the places where their child is active continues, it may be a factor that will reduce children's physical activities. This also means that unfavorable conditions will arise for the healthy development of children in the future. For this reason, future studies will guide the spatial preventions to be taken, determining the micro-scale qualities of physical activity places where parents create a negative perception of health safety. This will make an important contribution to the city planning and urban design literature, as well as provide important data for local governments and decision makers. The results of this study will inspire future studies in terms of determining Covid-19 and physical environmental characteristics that affect children's physical activity levels.

\section{Kaynakça/References}

Aarts, M., Wendel-Vos, W., Van Oers, H., Van Der Goor, I. ve Schuit, A. (2010). Environmental determinants of outdoor play in children: A large-scale cross sectional study, American Journal of Preventive Medicine, 39(3), 212-219.

Adkins, S., Sherwood, N., Story, M. ve Davis, M. (2004). Physical activity among AfricanAmerican girls: The role of parents and the home environment, Obesity Research, 12(9), 38-45.

Ainsworth, B., Haskell, W., Whitt, M., Irwin, M., Swartz, A., Strath, S., O'Brien, W. L., Bassett, D. R. Jr., Schmitz, K. H., Emplaincourt, P. O., Jacobs, D. R. Jr. ve Leon, A. S. (2000). Compendium of physical activities: An update of actvity codes and MET intensities, Medicine \& Science in Sports \& Exercise, 32(9), 498-516.

An, R. (2020). Projecting the impact of the coronavirus disease-2019 pandemic on childhood obesity in the United States: A microsimulation model, Journal of Sport and Health Science, 9, 302-312. 
Armitage, R. ve Nellums, L. (2020). Considering inequalities in th school closure response to COVID-19, The Lancet Global Health, 8, 644.

Armstrong, T. ve Bull, F. (2006). Development of the World health organization global physical activity questionnaire (GPAQ). Journal of Public Health, 14(2), 66-70.

Brodersen, N., Steptoe, A., Williamson, S. ve Wardle, J. (2005). Sociodemograohic, evelopmental, environmental, and psychological correlates of physical activity and sedantary behavior at age 11 to 12, Annals of Behavioral Medicine, 29(1), 2-11.

Bronfenbrenner, U. (1977). Toward an experimental ecology of human development, American Psychologist, 32(7), 513-531.

Burdette, H. ve Whitaker, R. (2005). A national study of neighborhood safety, outdoor play, television viewing, and obesity in preschool children, Pediatrics, 36(4), 657-662.

Christoffel, M., Gomes, A., Souza, T. ve Ciuffo, L. (2020). Children's (in)visibility in social vulnerability and the impact of the novel coronavirus (COVID-19), Revista Brasileira de Enfermagem, 73(2), e20200302.

Craig, C.L., Marshall, A.L., Sjöström, M., Bauman, A.E., Booth, M.L., Ainsworth, B.E., Pratt, M., Ekelund, U., Yngve, A., Sallis, J.F. ve Oja, P. (2003). International physical activity questionnaire: 12-country reliability and validity. Medicine and Science in Sports and Exercise, 35, 138-1395.

Çetintahra, G.E. (2015). Kentsel Alanda Fiziksel Çevrenin Çocuklarm Fiziksel Aktivitesi Üzerindeki Etkisi. Doktora Tezi. https://tez.yok.gov.tr/. (410526)

Çetintahra, G.E. ve Hepgüzel, B. (2014). Yürüyerek Ulaşım Tercihini Etkileyen Kentsel Olanak(sızlık)lar: Buca Alt Merkez Örneği - İzmir. 26. Uluslararası Yapı ve Yaşam Fuar ve Kongresi: Kent Merkezini Yeniden Keşfetmek içinde (411-416). Bursa: TMMOB Mimarlar Odası Bursa Şubesi.

Çetintahra, G.E. ve Çubukçu, E. (2019). Çocukların iç ve dış mekanlardaki aktivite düzeyleri: Akselerometre ve küresel konumlama sistemi aygtlarını kullanarak gerçek aktivite konumunun belirlenmesi, Kentli, 10(32), 47-50.

Dozier, S., Schroeder, K., Lee, J., Fulkerson, J. ve Kubik, M. (2020). The association between parents and children meeting physical activity guidelines, Journal of Pediatric Nursing, 52, 70-75.

Evans, G. (2003). The built environment and mental health, Journal of Urban Health, 80(4), 536-555.

Frank, L., Engelke, P. ve Schmid, T. (2003). Health and communty design. Washington: Island Press.

Frank, L., Andresen, M. ve Schmid, T. (2004). Obesity relationships with community design, physical activity, and time spent in cars, American Journal of Preventive Medici$n e, 27,27-96$.

Galaviz, K., Zytnick, D., Kegler, M. ve Cunningham, S. (2016). Parental perception of neighborhood safety and children's physical activity, Journal of Physical Activity and Health, 13(10), 1110-1116. 
Geldsetzer, P. (2020). Use of rapid online surveys to assess people's perceptions during infectious disease outbreaks: A cross-sectional survey on COVID-19, Journal of Medical Internet Research, 22(4), e18790.

Guerrero, M., Vanderloo, L., Rhodes, L., Faulkner, G., Moore, S., ve Tremblay, M. (2020). Canadian children's and youth's adherence to the 24-h movement guidelines during the COVID-19 pandemic: A decision tree analysis, Journal of Sport and Health Science, 9, 313-321.

Guillaume, M., Lapidus, L., Bjömtop, P. ve Lambert, A. (1997). Physical activity, obesity, and cardiovascular risk factors in children: The Belgan Luxembourg Child Study II, Obesity Research, 5(6), 549-556.

Handsa, A., Williamsa, S., Pearcea, G., Atkinsonb, L., Warka, P. ve Duncana, M. (2018). Parental perception of the built environment and children's active travel to school by deprivation level, Journal of Physical Activity \& Health, 15(10), 63.

Hemphill, N., Kuan, M., ve Harris,, K. (2020). Reduced physical activity during COVID19 pandemic in children with congenital heart disease, Canadian Journal of Cardiology, $36,1130-1134$.

Hesketh, K., Graham, M. ve Waters, E. (2008). Children's after-school activity: Associations with weight status and family circumstances, Pediatric Exercise Science, 20(1), 8494.

Heymann, D. ve Shindo, N. (2020). COVID-19: what is next for public health?, The Lancet, 395(10224), 542-545.

Hill, J., Wyatt, H., Reed, G. ve Peters, J. (2003). Obesity and the environment: Where do we go from here?, Science, 299, 853-855.

Heft, H. (1988). Affordances of children's environments: A functional approach to environmental description, Children's Environments Quarterly, 5(3), 29-37.

Hume, C., Ball, K. ve Salmon, J. (2006). Development and reliability of a self-report questionnaire to examine children's perceptions of the physical activity environment at home and in the neighborhood, International Journal of Behavioral Nutrition and Physical Activity, 3(1), 16.

Hume, C., Salmon J. ve Ball, K. (2007). Associations of children's perceived neighborhood environments with walking and physical activity, American Journal of Health Promotion, 21(3), 201-207.

Hume, C., Timperio, A., Salmon, J., Carver, A., Giles-Corti, B. ve Crawford, D. (2009). Walking and cycling to school: Predictors of increases among children and adolescents, American Journal of Preventive Medicine, 36(3), 195-200.

Hunter, S., Carson, V., Timperio, A., Salmon, J., Carver, A. ve Veitch, J. (2020). Moderators parents' perceptions of the neighborhood environment and children's physical activity, time outside, and screen time, Journal of Physical Activity and Health, 17(5), 557-565.

Kail, R. (2002). Children. New Jersey: Prentice Hall.

Kemperman, A. ve Timmermans, H. (2011). Children's recreational physical activity, Leisure Sciences, 33(3), 183-204. 
Korczak, D., Madigan, S. ve Colasanto, M. (2017). Children's physical actvity and depression: a meta-analysis, Pediatrics, 139(4), e20162266.

Li, M., Dibley, M., Sibbritt, D. ve Yan, H. (2006). Factors associated with adolescents' physical activity in Xi'an City, China. Medicine and Science in Sports and Exercise, 38(12), 2075-2085.

Lopez, R. (2004). Urban sprawl and risk for being overweight or obese, American Journal of Public Health, 94, 1574-1579.

Molnar, B., Gortmaker, S., Bull, F. ve Buka, S. (2004). Unsafto play? Neighborhood disorder and lack of safety predict reduces physical activity among urban children and adolescents, American Journal of health Promotion, 18(5), 378-386.

Mota, J., Almeida, M., Santos, P. ve Riberio, J. (2005). Perceived neighrborhood environments and physical activity in adolescents, Preventive Medicine, 41(4-5), 834-836.

Nader, P., Bradley, R., Houts, R., McRitchie, S. ve O'Brien, M. (2008). Moderate-tovigorous physical activity from ages 9 to 15 years, The Journal of the American Medical Association, 300(3), 295-305.

Nezami, N., Zarei, A., Tojari, F. ve Hazeveh, S. (2020). Correlation between parental support and physical activity, children's perception of parental support, social senc and neighborhood environment with child physical activity, Journal of Health Promotion Management, 9(2), 43-55.

Prince, S., Butler, G., Rao, D. ve Thompson, W. (2017). Where are children and adults physically active and sedentary? - A rapid review of location-based studies, Preventive Medicine Reports, 39(3), 130-135.

Saelens, B., Sallis, J., Nader, P., Broyles, S., Berry ve C., Taras, H. (2002). Home environmental influences on children's television watching from early to middle childhood, Journal of Developmental \& Behavioral Pediatrics, 23(3), 127-132.

Saelens, B., Sallis, J., Black ve J., Chen, D. (2003). Neighborhood-based differences in physical activity: An environmental scale evaluation, American Journal of Public Health, 93, 1552-1558.

Sallis, J., Alcaraz, J., McKenzie, T. ve Hovell, M. (1999). Predictors of change in children's physical activity over 20 mouths: Variations bugender and level of adiposity, American Journal of Preventive Medicine, 16(3), 222-229.

Shekerdmian, L., Mahmood, N., Wolfe, K., Riggs, B., Ross, C., McKiernan, C., et al. (2020). Characteristics and outcomes of children wih coronavrus diseases 2019 (COVID-19) infection admitted to US and Canadian pediatric intensive care units, JAMA Pediatrics.

Shi, Z., Lien, N., Kumar, B. ve Holmboe-Ottensen, G. (2006). Physical activity and associated socio-demographic factors among school adolescents in Jiangsu Province, China, Preventive Medicine, 43(3), 218-221.

Singh, G., Kogan, M., Siahpush, M. ve Van Dyck, P. (2008). Independent and joint effects of socioeconomic, behavioral,and neighborhood characteristics on physical inactivity and activity levels among US children and adolescents, Journal of Community Health, 33(4), 206-216. 
Sunnegårdh, J., Bratteby, L. ve Sjölin, S. (1985). Physical activity and sports involvement in 8-and 13-year-old children in Sweden, Acta Paediatrica Scandinavica, 74(6), 904.

Telford, A., Salmon, J., Jolley, D. ve Crawford, D. (2004). Reliability and validity of physical activity questionnaires for children: The children's leisure activities study survey (CLASS), Pediatric Exercise Science, 16, 64-78.

Timperio, A., Crawford, D., Telford, A. ve Salmon, J. (2004). Perceptions about the local neighborhood and walking and cycling among children, Preventive Medicine, 38(1), 39-47.

Thorleifsdottir, K. (2008). Neighborhood desgn: Associations between suburban neighborhood morphology and children's outdoor, out-of-school, physical activities (Doktora Tezi). https://repository.lib.ncsu.edu/. (etd-03282008-161919).

Trapp, G., Giles-Corti, B., Christian, H., Bulsara, M., Timperio, A., McCormack, G. ve Villaneuva, K.P. (2012). Increasing children's physical activity: Individual, socal, and environmental factors associated with walking toand from school, Health Education $\mathcal{E}$ Behavior, 39(2), 172-182.

Viner, R., Russell, S., Croker, H., Packer, J., Ward, J., Stansfield, C., Mytton, O., Bonell, C. ve Booy, R. (2020). School closure and management practices during coronavirus outbreaks including COVID-19: A rapid sytematic review, The Lancet Child \& Adolescent Health, 4, 397-404.

Wang, G., Zhang, Y., Zhao, J., Zhang, J. ve Jiang, F. (2020). Mitigate the effects of home confinement on children during the COVID-19 outbreak, The Lancet, 395(10228), 945947.

World Health Organization [WHO]. (2010). Global recommendations on physical activity for health. Switzerland: WHO Press.

World Health Organization [WHO]. (2014). Childhood overweight and obesity. 15 Nisan 2020 tarihinde https://www.icisleri.gov.tr/koronavirus-salgini-yeni-tedbirler adresinden erişildi.

World Health Organization [WHO]. (2016). Physical activity strategy for the WHO European Region 2016-2025. Copenhagen: WHO Regional Office for Europe.

World Health Organization [WHO]. (2019). Implementation framework for Phase VII (20192024) of the WHO European Healthy Cities Network: Goals, requirements and strategic approaches. Copenhagen: WHO Regional Office for Europe.

Yoshikawa, H., Wuermli, A., Britto, P., Dreyer, B., Leckman, J., Lye, S., et al. (2020). Effects of the global coronavirus disease-2019 pandemic on early childhood development: Short-and long-term risks and mitigating program and policy actions, Th Journal of Pediatrics, 223, 188-193.

Zhang, C., Zhang, R., Gan, Y., Li, D. ve Rhodes, R. (2019). Predicting transport-related cycling in Chinese employees using an integration of perceived physical environment and social cognitive factors, Transport Research Part F: Traffic Psychology and Behaviour, 64, 424-439.

Zorba, E. (2006). Yaşam boyu spor (2. bs.). İstanbul: Nobes Yayıncilık. 